order to bring about an arbitration in the United States a treaty negotiated by and with the consent of the Senate is necessary, and a majority of the Senate is not sufficient to consent to a treaty. The assent of two-thirds of the Senators is necessary before a treaty may be ratified by the President of the United States, and it was evident, not only before the repeal was requested by the President, but also after it was practically assured that the bill would be passed, that the consent of two-thirds of the Senators could not be obtained to submit the tolls question to arbitration.

\title{
THE EIGHTH ANNUAL MEETING OF THE SOCIETY
}

The Eighth Annual Meeting of the American Society of International Law was held, according to previous announcement, in Washington at the New Willard Hotel from April 22 to April 25, 1914. The general subject selected by the committee for consideration at the meeting was the Monroe Doctrine. The committee also placed upon the program the subject of the teaching of international law in American institutions of learning, as explained in an editorial comment of the Journal for January last. The codification of international law, which had been included in the program as a third subject for consideration, in anticipation of a report from the Committee on Codification, was not taken up at the meeting because the Committee found it impracticable to render a report at the present time and requested that the committee be continued which request was granted by the Society.

It was considered desirable and convenient to treat the two general subjects to be considered by the meeting separately by dividing the sessions between them and the program was arranged accordingly.

In pursuance of this plan the meeting was opened on Wednesday evening, April 22, 1914, at eight o'clock, by the Honorable Elihu Root, President of the Society, who took as the subject for his presidential address "The Real Monroe Doctrine." He was followed by Mr. Charles Francis Adams, of Boston, who described the origin of the doctrine. The subject was resumed at the session beginning at 2:30 o'clock on the afternoon of Thursday, April 23rd, by a consideration of the statements, interpretations and applications of the Monroe Doctrine and of more or less allied doctrines during three different periods of its history. The period from 1823-1845 was covered by Mr. William R. Manning, Adjunct Professor of Spanish American History in the University of 
Texas; from 1845-1870 by Mr. James M. Callahan, Professor and Head of the Department of History and Political Science of the University of West Virginia; from 1870 to the present time by Mr. John H. Latané, Professor and Head of the Department of History in Johns Hopkins University. The subject was continued at the evening session of the same day, at which three papers dealing with the misconceptions and limitations of the Monroe Doctrine were read,- - one by the Honorable John W. Foster, formerly Secretary of State of the United States, and Chairman of the Executive Committee of the Society; another by Mr. Leo S. Rowe, Professor of Political Science in the University of Pennsylvania, and the third by Mr. Eugene Wambaugh, Professor of International Law in Harvard Law School. At ten o'clock on the following morning Friday, April 24th, Professor William I. Hull, of Swarthmore College, spoke on a special topic "The Monroe Doctrine: National or International?" He was followed by Mr. Joseph Wheless, of St. Louis, Missouri, who pointed out what countries benefit by the doctrine. Professor Hiram Bingham, of Yale University, then gave the LatinAmerican attitude toward the doctrine. The final session devoted to this subject was held at eight o'clock Friday evening, April 24th. Two papers were read at this meeting, one by the Honorable Charlemagne Tower, formerly American Ambassador to Austria-Hungary, Russia and Germany, entitled "The European attitude toward the Monroe Doctrine," and the other by Professor George H. Blakeslee, of Clark University, who compared the Monroe Doctrine of 1823 with the doctrine of the present day and discussed the question whether the doctrine should continue to be a policy of the United States. The Honorable Charles B. Elliott, who was scheduled to speak on the same subject, was unable on account of illness to be present.

The consideration of the subject of the teaching of International Law was assigned to a conference of teachers of international law, invitations to participate in which were sent out by the President of the Society to leading educational institutions in the United States. Forty-one colleges and universities accepted the invitation and sent representatives to take part in the conference as follows:

Boston University, James F. Colby; Brown University, James C. Dunning; University of California, Orrin K. McMurray; University of Chicago, Ernst Freund; Clark College, George H. Blakeslee; Cornell University, Samuel P. Orth; Dartmouth College, James F. Colby, Frank A. Updyke; Dickinson College, Eugene A. Noble; George Washington 
University, Charles Noble Gregory, C. H. Stockton; University of Georgia, H. A. Nix; Hamilton College, Frank H. Wood; Harvard University, Eugene Wambaugh, George G. Wilson; University of Illinois, James W. Garner; Johns Hopkins University, James Brown Scott; University of Kansas, F. H. Hodder; Lafayette College, E. D. Warfield; Lehigh University, John L. Stewart; Louisiana State University, Arthur T. Prescott; University of Michigan, Jesse S. Reeves; University of Minnesota, William A. Schaper; University of Missouri, John D. Lawson; University of Nebraska, Edwin Maxey; College of the City of New York, Walter E. Clark; New York University, F. W. Aymar; Northwestern University, Charles Cheney Hyde; University of Notre Dame, William Hoynes; Oberlin College, Karl F. Geiser; University of Pennsylvania, Leo S. Rowe; University of Pittsburgh, Francis N. Thorpe; Princeton University, Philip Brown; Swarthmore College, William I. Hull; Syracuse University, Earl E. Sperry; University of Texas, William R. Manning; Tufts College, Arthur I. Andrews; Union College, Charles J. Herrick; University of Virginia, Raleigh C. Minor; Washington University, Edward C. Eliot; Western Reserve University, Francis W. Dickey; University of West Virginia, James M. Callahan; University of Wisconsin, Stanley K. Hornbeck; Yale University, Gordon E. Sherman.

The conference was opened by the Honorable Elihu Root on Thursday morning, April 23, 1914, at ten o'clock, with a short but very important address in which he showed his great interest in the subject. At the close of this session His Excellency Mr. da Gama, the Ambassador from Brazil, also addressed the delegates. The following points were placed before the conference for consideration and recommendations:

1. Plans for increasing the facilities for the study of international law; for placing the instruction on a more uniform and scientific basis; and for drawing the line between undergraduate and graduate instruction.

2 . The question of requiring a knowledge of the elements of international law for candidates for advanced degrees.

3. The advisability of urging all institutions with graduate courses in law to add a course in international law where not already given.

4. The advisability of calling the attention of the State bar examiners to the importance of requiring some knowledge of the elements of international law in examinations for admission to the bar.

5. The advisability of requesting the American Bar Association, through its appropriate committee, to consider the question of including the study of international law in its recommendations for a deeper and wider training for admission to the bar.

6. The desirability and feasibility of plans for securing the services of professors 
of or lecturers on international law to whom can be assigned definite lecture periods in institutions where international law is not now taught or is inadequately taughtthe services to rotate between institutions where they will be acceptable.

7. The advisability of requesting universities which now have summer schools to include among the subjects offered courses on the elements of international law, and, if there be occasion for it, to offer advanced courses of interest and profit for advaneed students and instructors.

Each of the foregoing questions was referred to a separate committee, upon which the delegates were appointed according to their expressed preferences. The seven committees were composed as follows:

Commitree No. 1.-William I. Hull, Chairman, Walter E. Clark, Karl F. Geiser, Charles Cheney Hyde, Raleigh C. Minor, Jesse S. Reeves, Leo S. Rowe, William A. Schaper, Gordon E. Sherman, Frank H. Wood.

Committee No. 2.-George H. Blakeslee, Chairman, James W. Garner, Stanley K. Hornbeck.

Committee No. 3.-James F. Colby, Chairman, F. H. Hodder, William Hoynes.

Commitree No. 4.--John D. Lawson, Chairman, Charles J. Herrick, Edwin Maxey, H. A. Nix, Samuel P. Orth.

Committee No. 5.-Edward C. Eliot, Chairman, Francis N. Thorpe, Eugene Wambaugh.

Commitrex No. 6.-Philip Brown, Chairman, Arthur I. Andrews, James M. Callahan, Francis W. Dickey, Arthur T. Prescott, E. D. Warfield.

Commititee No. 7.-William R. Manning, Chairman, F. W. Aymar.

The committees held a number of sessions and reported their recommendations to the full conference on Friday afternoon, April 24th, and Saturday morning, April 25th. The recommendations were discussed and considered in detail by the entire conference and adopted by it, either as reported by the committees or with modifications or amendments. The resolutions finally presented and adopted read as follows:

\section{Resolution No. 1}

Resolved, That the Conference of Teachers of International Law and Related Subjects hereby recommends to the American Society of International Law the appointment of a Standing Committee of the Society on the Study and Teaching of International Law and Related Subjects, upon lines suggested by the recommendations of the Conference.

Resolution No. 2

Resolved, That, in order to increase the facilities for the study of international law, 
the Conference hereby recommends that the following steps be taken to improve and enlarge library and reference facilities.

(a) That a carefully prepared bibliography of international law and related subjects be published, with the names of publishers and prices so far as these may be obtainable, with especial reference to the needs of poorly endowed libraries.

(b) That there be published likewise a carefully prepared index or digest of the various heads and sub-heads in international law, with references to all standard sources of authority upon each head.

(c) That there be published in a cheap and convenient form all documents of state, both foreign and domestic, especially Latin American, bearing upon international law, including treaties, documents relating to arbitration, announcements of state policy, and diplomatic correspondence, and that the aid of the Department of State be solicited in securing copies of such documents for publication.

(d) That at short intervals a bulletin be published, containing excerpts from the Congressional Record and other current sources, giving reliable information upon international questions arising from time to time and the final disposition of such questions.

(e) That a law reporter of international cases be issued.

\section{Resoldtion No. 3}

Resolved, That, in order further to increase the facilities for the study of international law, the Conference recommends that steps be taken to extend the study of that subject by increasing the number of schools at which courses in international law are given, by increasing the number of students in attendance upon the courses, and by diffusing a knowledge of its principles in the community at large, and, more particularly:

(a) That, as the idea of direct government by the people grows, it becomes increasingly essential to the well-being of the world that the leaders of opinion in each community be familiar with the rights and obligations of states, with respect to one another, as recognized in international law. Hence, it has become a patriotic duty, resting upon our educational institutions, to give as thorough and as extensive courses as possible in this subject.

(b) That a course in international law, where possible, should consist of systematic instruction extending over at least a full academic year, divided between international law and diplomacy.

(c) That prominent experts in international law be invited from time to time to lecture upon the subject at the several institutions.

\section{Resolution No. 4}

Resolved, That, with a view of placing instruction in international law upon a more uniform and scientific basis, the Conference makes the following recommendations:

(a) In the teaching of international law emphasis should be laid on the positive nature of the subject and the definiteness of the rules.

Whether we regard the teaching of value as a disciplinary subject or from the standpoint of its importance in giving to the student a grasp of the rules that govern the relations between nations, it is important that he have impressed upon his mind the definiteness and positive character of the rules of international law. The teaching 
of international law should not be made the occasion for a universal peace propaganda. The interest of students and their enthusiasm for the subject can best be aroused by impressing upon them the evolutionary character of the rules of international law. Through such a presentation of the subject the student will not fail to see how the development of positive rules of law governing the relations between states has contributed towards the maintenance of peace.

(b) In order to emphasize the positive character of international law, the widest possible use should be made of cases and concrete facts in international experience.

The interest of students can best be aroused when they are convinced that they are dealing with the concrete facts of international experience. The marshalling of such facts in such a way as to develop or illustrate general principles lends a dignity to the subject which can not help but have a stimulating influence.

Hence, international law should be constantly illustrated from those sources which are recognized as ultimate authority, such as: (a) cases, both of judicial and arbitral determination; (b) treaties, protocols, acts, and declarations of epoch-making congresses, such as Westphalia (1648), Vienna (1815), Paris (1856), The Hague (1899 and 1907), and London (1909); (c) diplomatic incidents ranking as precedents for action of an international character; (d) the great classics of international law.

(c) In the teaching of international law care should be exercised to distinguish the accepted rules of international law from questions of international policy.

This is particularly true of the teaching of international law in American institutions. There is a tendency to treat as rules of international law certain principles of American foreign policy. It is important that the line of division be clearly appreciated by the student. Courses in the foreign policy of the United States should therefore be distinctly separated from the courses in international law, and the principles of American foreign policy, when discussed in courses of international law, should always be tested by the rules which have received acceptance amongst civilized nations.

(d) In a general course on international law the experience of no one country should be allowed to assume a consequence out of proportion to the strictly international principles it may illustrate.

\section{Resolution No. 5}

Resolved, That the Conference recommends that a major in international law in a university course leading to the degree of doctor of philosophy be followed, if possible, by residence at The Hague and attendance upon the Academy of International Law which is to be established in that city; that it is the sense of the Conference that no better means could possibly be devised for affording a just appreciation of the diverse national views of the system of international law or for developing that "international mind" which is so essential in a teacher of that subject: and that therefore as many fellowships as possible should be established in the Academy at The Hague, especially for the benefit of American teachers and practitioners of international law.

\section{Resolution No. 6}

Resolved, That it is the conviction of this Conference that the present development of higher education in the United States and the place which the United States has now assumed in the affairs of the Society of Nations justify and demand that the 
study of the science and historic applications of international law take its place on a plane of equality with other subjects in the curriculum of colleges and universities and that professorships or departments devoted to its study should be established in every institution of higher learning.

\section{Resolution No. 7}

Resolved, That, in order adequately to draw the line between undergraduate and graduate instruction in international law, the Conference makes the foliowing recommendations:

Assuming that the undergraduate curriculum includes a course in international law, as recommended in Resolution No. 6, the Conferenee suggests that graduate instruction in international law concerns three groups of students:

(a) Graduate students in law;

(b) Graduate students in international law and political science;

(c) Graduate students whose major subjects for an advanced degree are in other fields, for example, history or economics.

The first two groups of students have a professional interest in international law, many having in view the teaching of the subject, its practice, or the public service. Therefore, as to them, the Conference recommends that the graduate work offered be distinctively of original and research character, somewhat as outlined in Resolution No. 4, following a preliminary training in the fundamental principles of the subject, as pursued in the undergraduate course or courses.

As to those of the third group, having less professional interest in international law, a broad general course in the subject is recommended.

\section{Resolution No. 8}

Resolved, That this Conference directs that a letter be sent to teachers of political science, law, history, political economy and sociology throughout the country calling attention to and emphasizing the essential and fundamental importance of a knowledge of international law on the part of students in those branches, which letter shall state the opinion of this Conference that every college of liberal arts, every graduate school and every law school, should have or make provision for courses in international law and urge that all graduate students working in the above mentioned fields be advised to include this subject in their courses of study.

Resolved, That, in accordance with the preceding resolution, there be prepared and sent out with this letter reprints of Senator Root's article entitled "The need of popular understanding of international law," which appeared in Vol. 1 of the American Journal of International Law, and of his address delivered at the opening of this Conference.

Resolved, That the Recording Secretary of the American Society of International Law attend to the drafting, printing and distribution of the above specified letter and reprints and that he is hereby authorized, if he sees fit, to send out additional literature therewith.

\section{Resolution No. 9}

Resolved, That, in recognition of the growing importance of a knowledge of international law to all persons who plan to devote themselves to the administration of 
justice, and who, through their professional occupation, may contribute largely to the formation of public opinion and who often will be vested with the highest offices in the State and nation, this Conference earnestly requests all law schools which now offer no instruction in international law to add to their curriculum a thorough course in that subject.

Resolved further, That a copy of this resolution be sent to all law schools in the United States.

\section{Resolution No. 10}

Resolved, That the Conference hereby calls the attention of the State bar examiners and of the bodies whose duty it is to prescribe the subjects of examination, to the importance of requiring some knowledge of the elements of international law in examinations for admission to the bar, and urges them to make international law one of the prescribed subjects.

\section{Resolution No. 11}

Resolved, That the Conference hereby requests the American Bar Association to take appropriate action toward including international law among the subjects taught in law schools and required for admission to the bar.

\section{Resolution No. 12}

Resolved, That the Conference hereby adopts the following recommendations:

(a) That it is desirable, upon the initiative of institutions where instruction in international law is lacking, to take steps toward providing such instruction by visiting professors or lecturers, this instruction to be given in courses, and not in single lectures, upon substantive principles, not upon popular questions of momentary interest, and in a scientific spirit, not in the interest of any propaganda.

(b) That members of the American Society of International Law, qualified by professional training, be invited by the Executive Council or the Executive Committee of the Society to give such courses, and that provision be made, through the establishment of lectureships or otherwise, to bear the necessary expenses of the undertaking;

(c) That the Standing Committee on the Study and Teaching of International Law and Related Subjects of the American Society of International Law, the appointment of which was recommended in Resolution No. 1, be requested to ascertain what institutions are in need of additional instruction in international law and endeavor to find means of affording such assistance as may be necessary to the teaching staff of the said institutions or of supplying this additional instruction by lecturers chosen by the said Committee and approved by the Executive Council or Executive Committee.

(d) That steps be taken to bring to the attention of every college at present not offering instruction in international law the importance of this subject and the readiness of the American Society of International Law, through its Standing Committee on the Study and Teaching of International Law and Related Subjects, to coöperate with such institutions in introducing or stimulating instruction. 


\section{Resolution No. 13}

Resolved, That this Conference hereby requests and recommends that universities having summer schools offer summer courses in international law.

Resolved further, That the American Society of International Law, through its Standing Committee on the Study and Teaching of International Law and Related Subjects, is hereby requested to endeavor to stimulate a demand for courses in international law in summer schools.

\section{Resolution No. 14}

Resolved, That the Conference recommends the establishment and encouragement in collegiate institutions of specialized courses in preparation for the diplomatic and consular services.

\section{Resolution No. 15}

Resolved, That the Conference recommends that the study of international law be required in specialized courses in preparation for business.

\section{Resolution No. 16}

Resolved, That a Committee of Revision, consisting of ten members, of which $\mathrm{Mr}$. James Brown Scott shall be chairman ex officio, be appointed by the Chair for the revision in matters of form of the various resolutions and recommendations made to this Conference by the different committees and subcommittees and adopted by it, the said Committee of Revision to send a copy of the said resolutions and recommendations to every law school, college and university in the United States and to the American Society of International Law, through its Executive Council or Executive Committee, for such action as will serve to effectuate the recommendations of the Conference.

The following members were, in accordance with Resolution No. 16, appointed on the Committee of Revision, which prepared the resolutions in the form above given: Robert Bacon, George H. Blakeslee, Philip Brown, James F. Colby, Edward C. Eliot, John W. Foster, William I. Hull, John D. Lawson, William R. Manning, Elihu Root.

Space will not permit at this time of any comment upon the significance and importance of the action taken by the conference. The bare facts have been recorded for the readers of the Journal, who will be informed through these columns of subsequent lines of action which may be developed from this conference, which may turn out to be an epochmaking step in fostering the study and teaching of international law.

The business meeting of the Society was held on Saturday morning, April 25th, immediately after the adjournment of the conference of teachers of international law. The following officers were elected for the ensuing year: 


\section{President}

Hon. Elihu Root

Vice-Presidents

Chief Justice White

Justice Wilutam R. Day

Hon. P. C. KNox

Mr. Andrew Carnegie

Hon. Joseph H. Choate

Hon. John W. Foster

Hon. George Gray
Hon. William W. Morrow

Hon. Richard OlNey

Hon. Horace Porter

Hon. Oscar S. Strauts

Hon. JACOB M. Dickinson

HoN. James B. ANgell

Hon. William H. Taft

\section{Hon. William J. BRYAN}

\section{Members of the Executive Council to serve until 1917}

Hon. Richard Bartholdt, Mis- Gen. George B. Davis, Dissouri trict of Columbia

Prof. Charles Noble Gregory, Hon. A. J. Montague, VirDistrict of Columbia ginia

Rear Admiral Charles H. Stock- Charles B. Warren, Esq., TON, District of Columbia Michigan

Hon. John Sharp Williams, Mis- Prof. Theodore S. Woolsey, sissippi

Connecticut

Member of the Executive Council to serve until 1916, in place of the late Senator Bacon

Hon. Henry Cabot Lodge, Massachusetts

As an honorary member of the Society, the standing committee recommended, and the Society elected, Signor Pasquale Fiore, Senator of Italy, member of its Council on Diplomatic Affairs, member of the Institute of International Law, Professor of International Law in the University of Naples.

At the meeting of the Executive Council, which took place immediately upon the adjournment of the Society, the following additional officers and committees were chosen: 
Chairman of the Executive Council, Hon. John W. Foster Executive Committee

Hon. Eluhu Root

Hon. George Gray

JACKSON H. RALston, EsQ.
Hon. Robert Lansing

Hon. John Bassett Moore

Prof. George G. Wilson

Hon. Oscar S. Straus

\section{Ex-Officio}

Hon. John W. Foster, Chairman

JAMEs BRown Scott, Esq., Recording Secretary

Charles Henry Butler, Esq., Corresponding Secretary

Hon. Chandler P. Anderson, Treasurer

Editorial Board of the American Journal of International Law

JaMES Brown ScotT, Editor-in-Chief

Chandler P. Anderson George W. Krrchwey

Charles Noble Gregory Robert lansing

Amos S. Hershey John Bassett Moore

Charles Cheney Hyde George G. Wilson

THEODORE S. WOOLSEY

Grorge A. Finch, Secretary of the Board of Editors and Business Manager of the Journal

\section{Committees}

Standing Committee on Selection of Honorary Members: George G. Wilson, Chairman; Jackson H. Ralston, Theodore S. Woolsey.

Standing Committee on Increase of Membership: James Brown Scott, Chairman; Charles Cheney Hyde, John H. Latané, Jesse S. Reeves, Theodore S. Woolsey.

Auditing Committee: Clement L. Bouvé, Jackson H. Ralston.

Committee on Codification: Elihu Root, Chairman, ex-officio; Chandler P. Anderson, Charles Henry Butler, Lawrence B. Evans, Charles Noble Gregory, Robert Lansing, Paul S. Reinsch, Leo S. Rowe, James Brown Scott, George G. Wilson.

Committee on Publication of Proceedings: George A. Finch, Otis T. Cartwright. 
Committee on Ninth Annual Meeting: James Brown Scott, Chairman; Philip Brown, James W. Garner, Robert Lansing, Walter S. Penfield, Jackson H. Ralston, Eugene Wambaugh.

The annual meeting closed as usual with a banquet on Saturday evening, April 25th. Mr. Root presided as toastmaster and the other speakers of the evening were the honorable William Jennings Bryan, Secretary of State, the Honorable F. C. Stevens, Member of Congress from Minnesota, and Mr. Archibald C. Coolidge, recently exchange professor in Germany of Harvard University. While the members of the Society who attended the banquet expectantly awaited the remarks of the Secretary of State, in view of the critical state of the relations between the United States and Mexico, growing out of the occupation of Vera Cruz a few days previously by the naval forces of the United States, he took them completely by surprise by announcing and incorporating in his remarks the text of the exchange of notes, completed just before he entered the banquet hall, between the United States and the representatives of Argentina, Brazil and Chile, offering and accepting the mediation of the three latter countries in an endeavor to prevent further armed conflict between the United States and Mexico.

The plan adopted this year of dividing the meeting between sessions devoted exclusively to professional and scientific discussions and others devoted to the presentation of the subjects in a way to appeal to a more popular audience seems to have worked exceptionally well, as the meetings were better attended than any since the Society's existence. The plan is likely to be followed and perhaps improved upon for the future meetings of the Society.

THE LAKE MOHONK CONFERENCE ON INTERNATIONAL ARBITRATION

The twentieth annual meeting of the Lake Mohonk Conference on International Arbitration was held in the last week of May and, as usual, was attended by a large and influential body of men and women interested in the peaceful settlement of international disputes and the means by which such settlement may be advanced. The conference had the great advantage of having as chairman, Mr. John Bassett Moore, late counselor for the Department of State, and in a careful, thoughtful and valuable address he showed that our government had repeatedly sobmitted disputes to arbitration, which would be excluded 